\title{
USING GIS FOR DEVELOPING SUSTAINABLE URBAN GROWTH CASE KYRENIA REGION
}

\author{
Can Kara ${ }^{1},{ }^{*}$ Nuhcan Akçit $^{2, *}$ \\ ${ }^{1}$ Nearest University, Nicosia, Faculty of Architecture, Nicosia Cyprus, Email: can.kara@ neu.edu.tr \\ ${ }^{2}$ Department of Geodetic and Geographic Information Technology Middle East Technical University Ankara, Turkey, \\ E-mail: nuhcan@metu.edu.tr
}

KEY WORDS: GIS, MCE, Sustainable Urban Growth, Urban Analysis, Kyrenia

\begin{abstract}
:
It is critical to develop urban layers for analysis sustainable urban development possibilities within planning process. Kyrenia Region has many physical, environmental or economic issues that may danger the growth possibilities in sustainable manner. From this point, this study uses different spatial layers such as slope, distance to roads, distance to central zone, vegetation, soil productivity, environmental protection zones, distance to open/green space, distance to education for supporting sustainable urban growth policies and define suitable areas for urban development within this perspective. The study tries to convert sustainable urban growth policies such as; compact growth, environmental protection, equal accessibility to basic services; into spatial layers and establish proper framework for multi criteria evaluation in Kyrenia Region within using geographical information systems. It shows suitability values for Kyrenia region and constraints zones at final section. It clearly presents the suitable areas for the sustainable urbanization and also unsuitable or risky areas for reducing the possible disasters and may happen in the future.
\end{abstract}

\section{INTRODUCTION}

GIS is one of the formalised computer-based information system which is suitable integrating data from various sources to maintain the information. This information is very important using practical decision-making in urban planning (Han 1989).Land use suitability assessment which is a crucial application in urban planning and land use management, provides fundamental base for planning through decision making process.(Long Y. 2009) Many researchers and planners have created detailed applications for many case studies and explore different perspectives about land suitability assessment for this issues(Lingjung L. 2008; AbuSada, J. 2011; Wang, H., 2013).

In general, this study concentrates on using GIS and MCE to produce suitability maps as spatial factors of urban growth. Accordingly, it aims to construct sustainable urban development goals and perspectives and converting them as spatial criteria choices.

\section{STUDY AREA}

The Study area is located in the northern part of Cyprus Island. It covers an area of 637 square kilometre area and 69163 population in 2011(State Planning Organization, 2011) From 2004, due to the Annan Plan period. This rapid urbanization has brought many problems in the region such as loss of primary soils and vegetation, piecemeal growth in housing environments and decrease in accessibility to social amenities or green space and others (Kara, 2016).

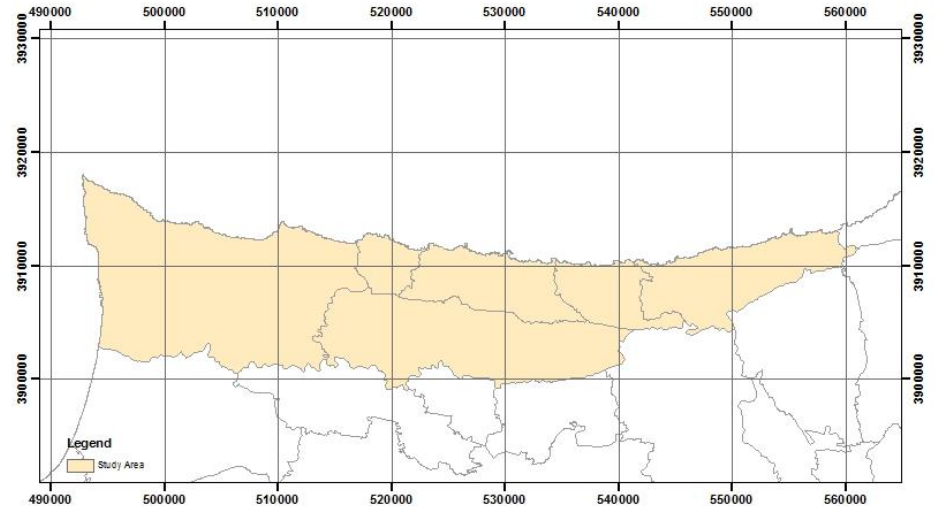

Figure 1: Location map of study area

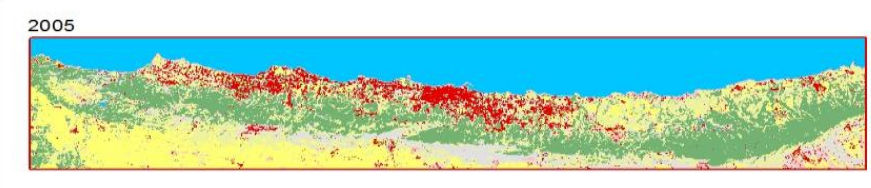

2015

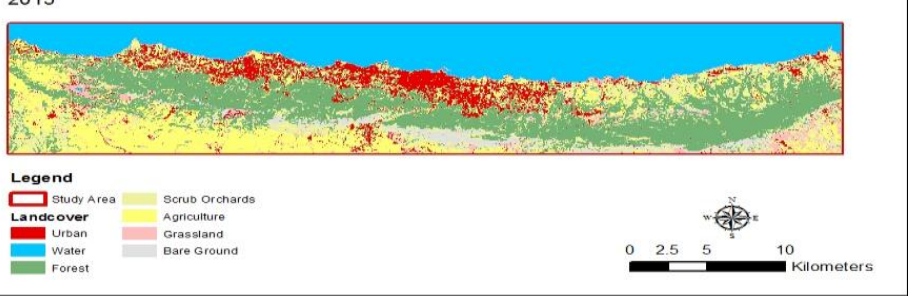

Figure 2: Urban Change in Kyrenia region (Kara, 2016) 


\section{DATA AND METHODS}

\subsection{Data}

In general, data availability is so critique to establish comprehensive model for defining urban growth suitability in terms of sustainable development. Therefore, possible local offices are checked to set up geographical information data. Due to that sustainable urban growth requires many principles, it is important to develop many alternative spatial layers to cover different policies. Spatial data layers are given by the following section (Table 1). These layers than converted as multi criteria maps according to the study analysis.

\begin{tabular}{|l|l|}
\hline \multicolumn{1}{|c|}{ Name } & \multicolumn{1}{c|}{ Source } \\
\hline Road Network & $\begin{array}{l}\text { Developed from 2016 } \\
\text { Sat Images }\end{array}$ \\
\hline Land Use & $\begin{array}{l}\text { Town Planning } \\
\text { Kyrenia Municipality }\end{array}$ \\
\hline Surface Water Resources & Waterworks \\
\hline Ground Water Resources & Geology and Mining \\
\hline Environmentally Sensitive Areas & Agriculture \\
\hline Soil Classification & $\begin{array}{l}\text { Environmental } \\
\text { Protection }\end{array}$ \\
\hline Vegetation & Mapping Department \\
\hline Slope & Kyrenia Municipality \\
\hline Satellite Images 2016 & \\
\hline Google Earth & \\
\hline
\end{tabular}

Table 1. Spatial data source for the study.

\subsection{GIS-based multi-criteria evaluation}

In order to analyze suitable areas for sustainable urban growth in Kyrenia region, it is required to select proper sustainable urban growth policies. Sustainable urban growth policies were constructed from not only literature but also local experts' interview. These are grouped into three main policy and sub policies that can be converted into spatial criteria for a multicriteria evaluation process (Figure 3). Each policy is transferred to spatial parameters for improving the land use suitability degree within MCE based Urban Growth Modelling within Sustainable Urban Growth policies. In other words, they are defined as site selection criteria. Suitability is calculated according to the equation 1 (Eastman, 2001).

$$
S=\sum_{j=1}^{n} W j X i j
$$

where $\quad W j=$ Relative importance weight of criteria $j$ $\mathrm{Xji}=$ the standardizing value of area $\mathrm{i}$ under criterion $\mathrm{j}$ $\mathrm{n}=\mathrm{is}$ the number of criteria

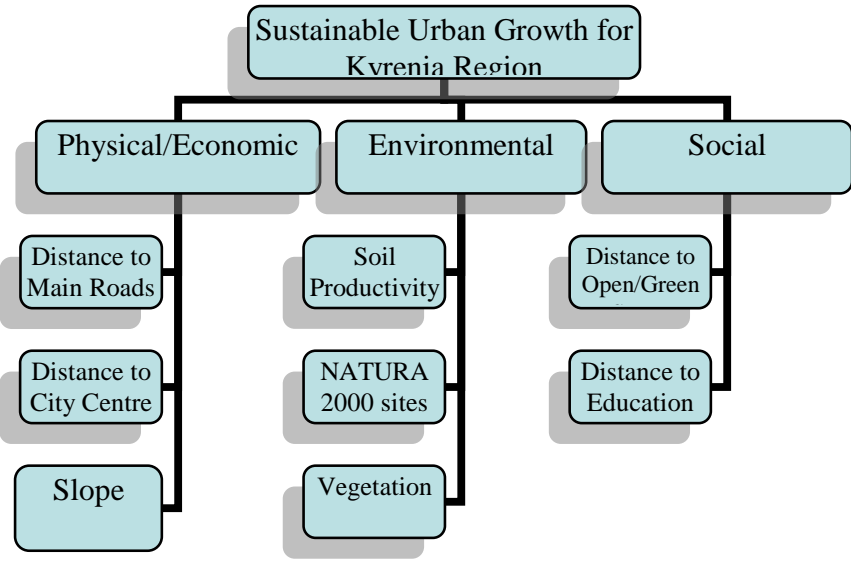

Figure 3: MCE Model for assessing Sustainable Urban Growth for Kyrenia

\subsubsection{Criteria Description}

In the following section, criteria (economic, environmental or social) and sub-criteria that are used for Sustainable Urban Growth in Kyrenia region are explained.

\subsubsection{Slope:}

Slope is one of the basic criteria to be considered in economic terms. It is suggested to select flat areas for development and continuity of the urban growth. Therefore, 0-5 percent, 5-10 percent, 10-15 percent, 15-20 percent (Figure 4)

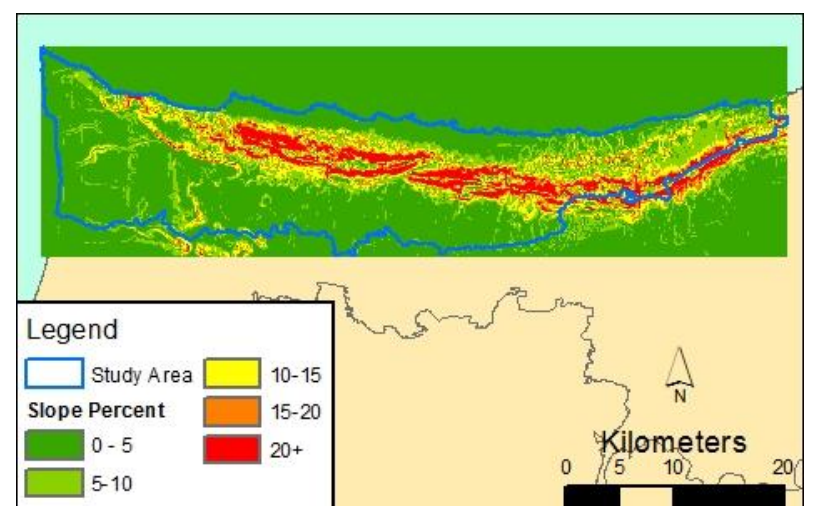

Figure 4: Slope criteria map

\subsubsection{Distance to Central Zone:}

Kyrenia has very powerful but limited central zone and it has still empty spaces for development. Additionally, it has small zones that can be re-generated. Therefore, it is important to first using central zone for growth then proximate areas should be developed. In order to have compact and smarth growth opportunities for sustainable urban development in Kyrenia region linear growth should be avoided. Within this perspective, areas within $0-1 \mathrm{~km}, 1-5 \mathrm{~km}$ and $5 \mathrm{~km}+$ zones were determined for the evaluation (Figure 5). 


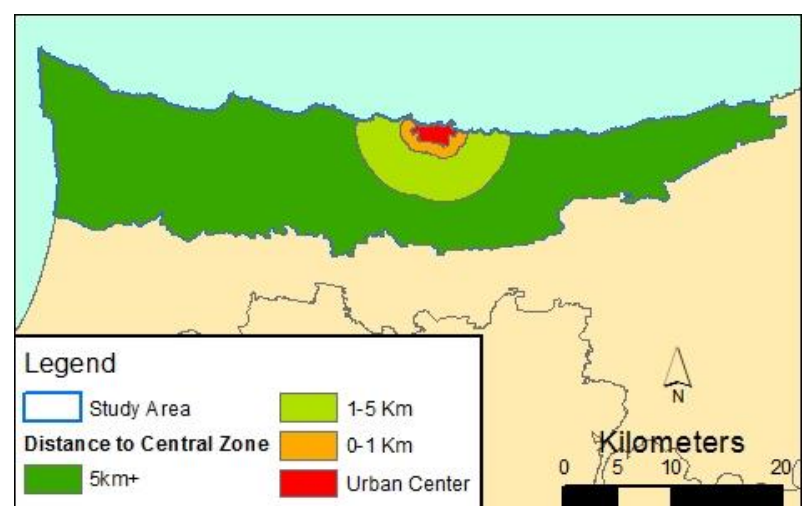

Figure 5: Distance to central zone criteria map

\subsubsection{Distance to Main Roads:}

It is important to use existing areas that have connection primary roads. From that point, areas within $0-250 \mathrm{~m}, 250-500 \mathrm{~m}$ $500-1000 \mathrm{~m}$ and $1000 \mathrm{~m}+$ zones were determined for the evaluation (Figure 6).

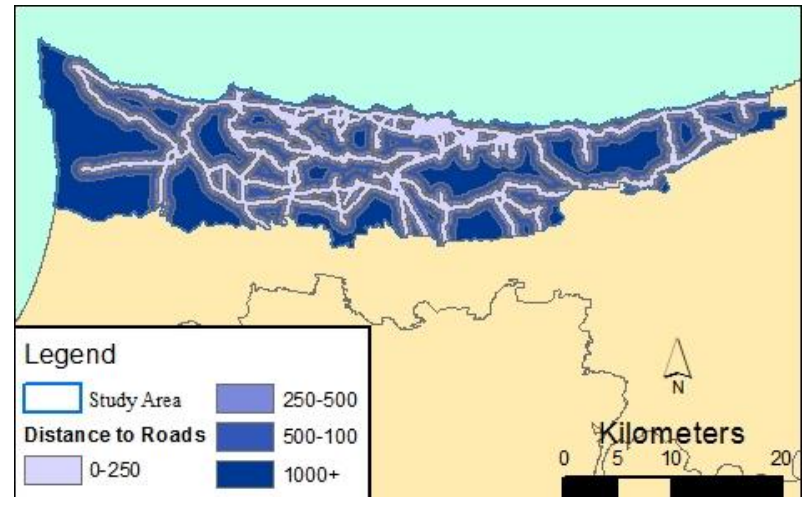

Figure 6: Distance to roads criteria map

\subsubsection{Soil Productivity:}

In general, 1st and 2nd classes are reserved for agricultural activities with the 3rd, 4th 5th 6th and 7th are suitable for dry agriculture and forestry. Therefore, areas within the 1st and 2nd classes were classified as exclusionary zones for analysis. the 3rd and 4th combined into one class, 5th and 6th into another one and 7 th is defined as different class for analysis. According to the Cukurova University, existing urban zones are not surveyed in 2000. Therefore, some parts of the study area doesn't have proper soil productivity information (Figure 7).

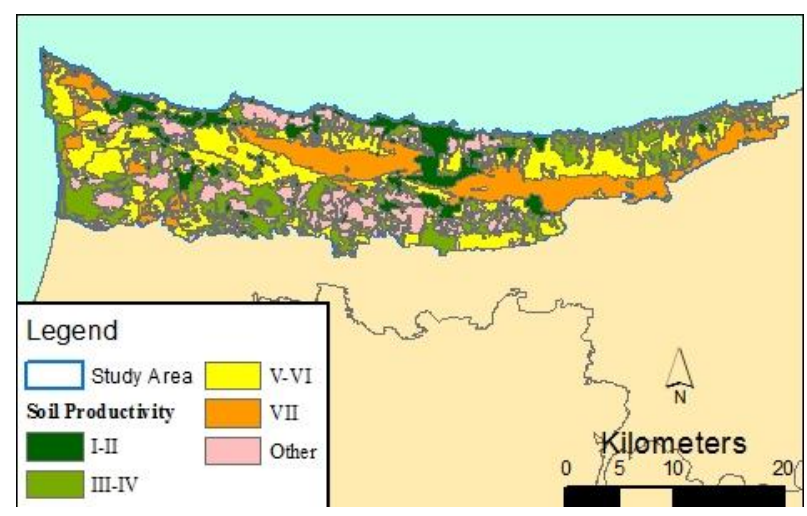

\subsubsection{Environmental Protection Areas:}

There are internationally recognized environmental areas in Kyrenia Region. Akdeniz (Ag Irini) Kyrenia Mountains (Pentadaktylos), and Alagadi (Alakati) areas are listed as NATURA 2000 areas. Therefore, these areas added as constraints for evaluation. Areas within $0-500 \mathrm{~m}, 500-1000 \mathrm{~m}$ and $1000 \mathrm{~m}+$ zones were determined for the evaluation (Figure8).

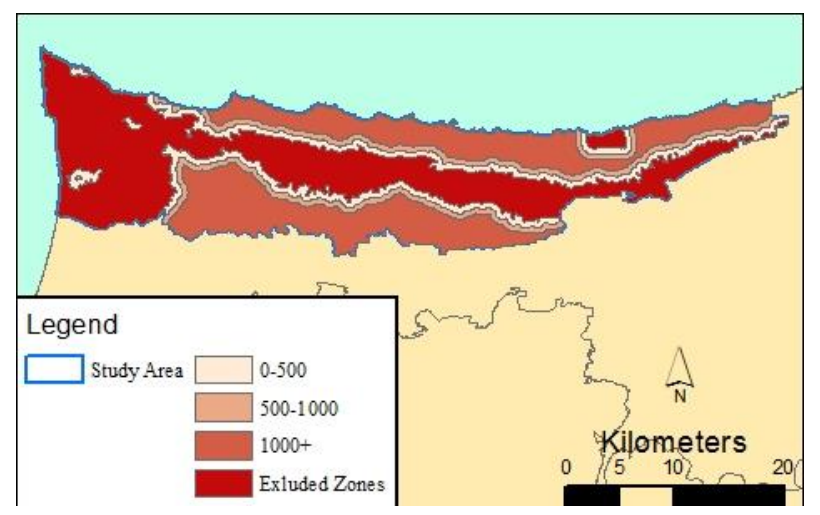

Figure 8: Distance to Natura 2000 zones criteria map

\subsubsection{Vegetation:}

Additional to Environmental Protection Areas in Cyprus, it's important to protect the ecological uniqueness of the regional vegetation. Several vegetation classes have agricultural activities and different forests types must be selected as constraints and should be subtracted from assessment process. Forest Needle, and Forest Eucalyptus were determined as constraints for evaluation. Grass, Ag-Orchards Bare ground, Irrigated Agriculture, Dry Pasture and grassland were selected in different zones for evaluation (Figure 9).

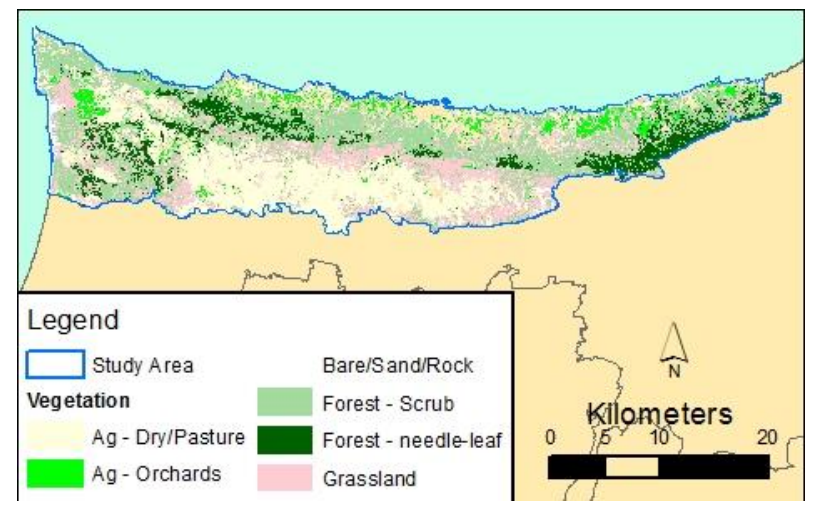

Figure 9: Vegetation criteria map

\subsubsection{Distance to Open/Green Space:}

It is also important to have equal accessibility for green and open spaces within urban environments. Therefore, areas within $0-300 \mathrm{~m}, 300-1000 \mathrm{~m}$ and $1000 \mathrm{~m}+$ zones were determined for the evaluation (Figure 10).

Figure 7: Soil productivity criteria map 


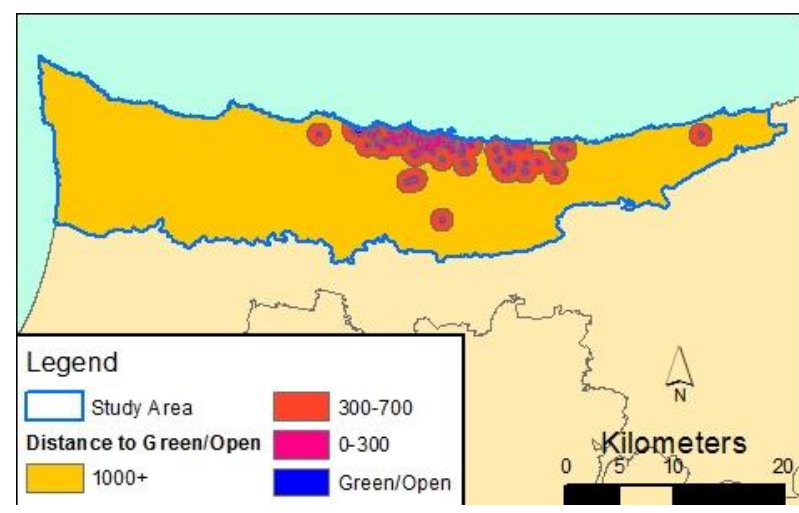

Figure 10: Distance to green/open space criteria map

\subsubsection{Distance to Education}

In addition to green space accessibility, it is also crucial to have efficient accessibility to educational services. Therefore, Areas within $0-500 \mathrm{~m}, 500-1000 \mathrm{~m}$ and $1000 \mathrm{~m}+$ zones were determined for the evaluation (Figure 11).

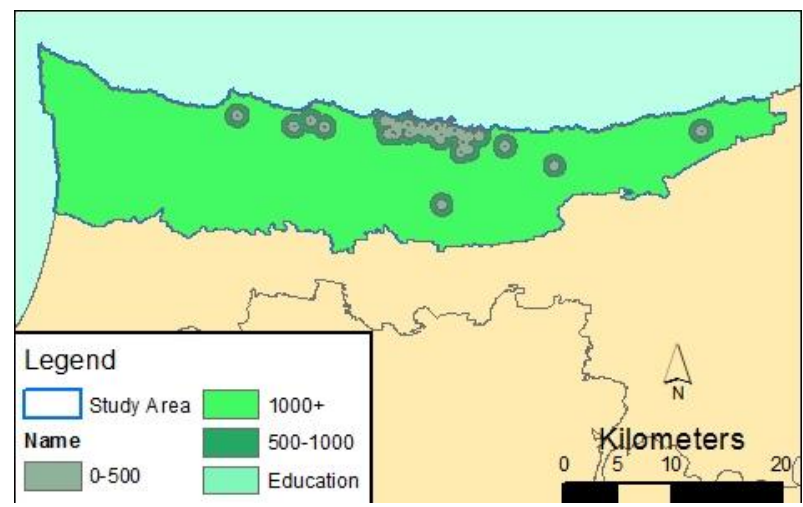

Figure 11: Distance to education criteria map

After the development of spatial criteria set, it is required to define criteria weights. Pairwise comparison matrices were formed by the interviews with various experts and stakeholders from different institutions. Decision-makers such as Town Planner, architects, Geology Engineer, Civil Engineer, Environmental Engineer, etc. ranked each criteria weights by comparing and filling the matrices. After that, CR values for each comparison table were checked to confirm the reliability of these experts' choice. According to the (Saaty, 1980) CR should have a value of less than 10 percent. In this study, CR values have lower values than the 10 percent which indicate the consistency of the pairwise comparison.

\begin{tabular}{|l|l|}
\hline $\begin{array}{l}\text { Intensity of } \\
\text { Importance }\end{array}$ & Definition \\
\hline 1 & Equal importance \\
\hline 3 & Weak importance of one over another \\
\hline 5 & Essential or strong importance \\
\hline 7 & Demonstrated importance \\
\hline 9 & $\begin{array}{l}\text { Intermediate values between the two } \\
\text { adjacent } \\
\text { judgments }\end{array}$ \\
\hline $\begin{array}{l}\text { Reciprocals of } \\
\text { above nonzero }\end{array}$ & $\begin{array}{l}\text { If activity i has one of the above } \\
\text { nonzero numbers assigned to it when } \\
\text { compared with activity } \mathrm{j} \text {, then } \mathrm{j} \text { has the } \\
\text { reciprocal value when compared with } \mathrm{i}\end{array}$ \\
\hline
\end{tabular}

Table 2: Pair-wise comparison values for AHP (Saaty, 1994)

\begin{tabular}{|c|c|c|c|c|c|}
\hline $\begin{array}{l}\text { Main } \\
\text { Criteria }\end{array}$ & Weights & $\mathrm{CR}$ & Criteria & Weights & $\mathrm{CR}$ \\
\hline \multirow{3}{*}{ 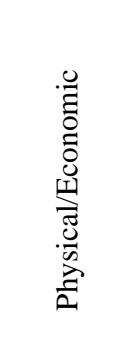 } & \multirow{3}{*}{0,16} & & $\begin{array}{l}\text { Distance to } \\
\text { Central Zone }\end{array}$ & 0,55 & \multirow{3}{*}{0,02} \\
\hline & & & $\begin{array}{l}\text { Distance to } \\
\text { Roads }\end{array}$ & 0,24 & \\
\hline & & & Slope & 0,21 & \\
\hline \multirow{3}{*}{ 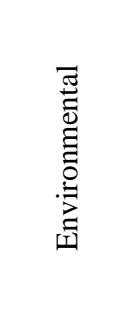 } & \multirow{3}{*}{0,54} & 0,01 & Vegetation & 0,23 & \multirow{3}{*}{0,03} \\
\hline & & & $\begin{array}{l}\text { Soil } \\
\text { Productivity }\end{array}$ & 0,65 & \\
\hline & & & EPZ & 0,12 & \\
\hline \multirow{2}{*}{ 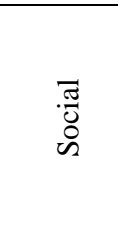 } & \multirow{2}{*}{0,30} & & $\begin{array}{l}\text { Distance to } \\
\text { Green/Open } \\
\text { Space }\end{array}$ & 0,50 & \multirow{2}{*}{0,0} \\
\hline & & & $\begin{array}{l}\text { Distance to } \\
\text { Educational } \\
\text { Services }\end{array}$ & 0,50 & \\
\hline
\end{tabular}

Table 3: Main criteria and criteria weights and CR values

\begin{tabular}{|c|c|c|}
\hline Sub-criteria & Weights & CR \\
\hline $0-1 \mathrm{~km}$ & 0,65 & \multirow{3}{*}{0,02} \\
\hline $1-5 \mathrm{~km}$ & 0,25 & \\
\hline $5 \mathrm{~km}+$ & 0,10 & \\
\hline $0-250 \mathrm{~m}$ & 0,48 & \multirow{4}{*}{0,03} \\
\hline $250-500 \mathrm{~m}$ & 0,27 & \\
\hline $500-1000 \mathrm{~m}$ & 0,17 & \\
\hline $1000 \mathrm{~m}+$ & 0,08 & \\
\hline $0-5$ & 0,48 & \multirow{4}{*}{0,01} \\
\hline $5-10$ & 0,27 & \\
\hline $10-15$ & 0,16 & \\
\hline $15-20$ & 0,09 & \\
\hline Ag/Dry & 0,44 & \multirow{5}{*}{0,04} \\
\hline Bare/Sand/Rock & 0,20 & \\
\hline Grassland & 0,21 & \\
\hline Ag/Orchards & 0,09 & \\
\hline Forest/Scrub & 0,06 & \\
\hline III and IV & 0,11 & \multirow{3}{*}{0,05} \\
\hline $\mathrm{V}$ and VI & 0,26 & \\
\hline $\mathrm{VII}+$ & 0,63 & \\
\hline $0-500 \mathrm{~m}$ & 0,57 & \multirow{3}{*}{0,0} \\
\hline $500-1000 \mathrm{~m}$ & 0,29 & \\
\hline $1000 \mathrm{~m}+$ & 0,14 & \\
\hline $0-300 \mathrm{~m}$ & 0,58 & \multirow{3}{*}{0,0} \\
\hline $300-1000 \mathrm{~m}$ & 0,31 & \\
\hline $1000 \mathrm{~m}+$ & 0,11 & \\
\hline $0-500 \mathrm{~m}$ & 0,67 & 0,01 \\
\hline
\end{tabular}




\begin{tabular}{|l|l|l|}
\hline $500-1000 \mathrm{~m}$ & 0,24 & \\
\cline { 1 - 2 } $1000 \mathrm{~m}+$ & 0,09 & \\
\hline
\end{tabular}

Table 4: Main criteria and critera weights and CR values

\section{RESULTS}

In order to have final suitability analysis, 8 different criteria maps are converted into raster format and their cell values and attributes are updated with criteria weights. After that raster calculator is used to multiple criteria weights and sum up all values. Additionally, constraint map is also multiplied with the final suitability raster layer for presenting and analyzing unsuitable areas for the study area (Table 5 ). Approximately, 388 square kilometer of the total area is updated as constraint area of the total area.

\begin{tabular}{|l|}
\hline -Antiquities Sites \\
\hline -River Streams Dams, Wetlands \\
\hline -Soil with I and II Classes \\
\hline -Forest Needle and Forest Eucalyptus \\
\hline -Areas have 20 percent slope \\
\hline -Environmental Protection Zones \\
\hline
\end{tabular}

Table 5: Areas that excluded from suitability analysis

249 square kilometer of the area can be used for urban growth according to the results. As can be seen from the final suitability map (Figure 12), there are high suitable areas in northern part of the study area. On the other hand, southern part of the study area have lower suitability values for sustainable urban growth. Only small zones that are closer to existing road network and urban zones have higher values in southern part of the Kyrenia region. Additionally, eastern part of the region has some areas with proper suitability values that over 0,25 and 0,30 .

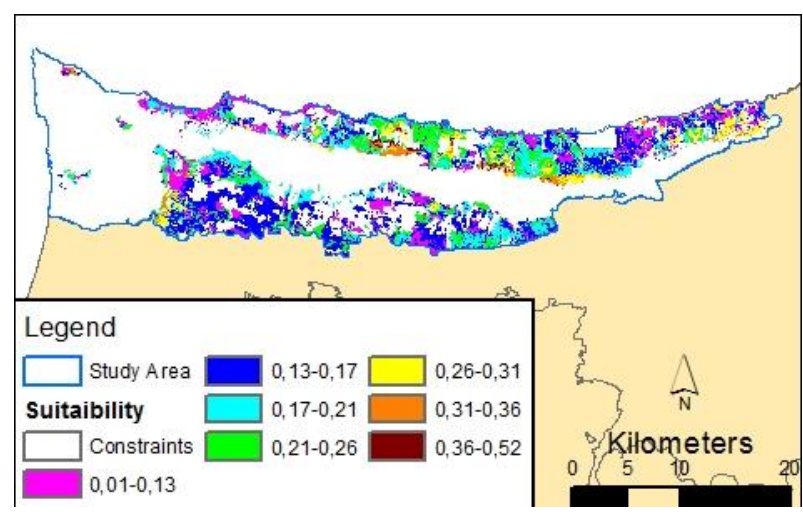

Figure 12: Final suitability map

\section{CONCLUSION}

The paper discuss about the suitability analysis in Kyrenia region.In this work 8 criteria use $\mathrm{d}$ for analysis but can be expanded more criteria and/or different weights to the criteria which are based on analysis type.The main criteria and weights are depend on the importance of the criteria based on the vision of the planning issues. Protecting critical issues in the cities while planning is the key idea. One of the primary asset protecting environment and ecology. There is high potential using GIS MCE for evaluation in land use rural and urban planning. This improves scientific of land use planning.It contribute a better platform for land suitability evaluation of urban and rural planning. Further more analysis and improvements can be done for this issue future research.

\section{REFERENCES}

Han, S.Y. and Kim, T.J., 1989. Can expert systems help with planning?. Journal of the American Planning Association,55(3), pp.296-308.

Long, Y., Mao, Q. and Dang, A., 2009. Beijing Urban Development Model: Urban Growth Analysis and Simulation.Tsinghua Science \& Technology, 6(14), pp.782-794.

Lingjun, L., Zong, H. and Yan, H., 2008. Study on land use suitability assessment of urban-rural planning based on remote sensing - a case study of Liangping in Chongqing.

Kara, C., 2013. Simulating sustainable urban growth by using GIS and MCE based CA. The case of Famagusta, Nort Cyprus (Doctoral dissertation, Eastern Mediterranean University (EMU)-Doğu Akdeniz Üniversitesi (DAÜ)).

AbuSada, J. and Thawaba, S., 2011. Multi criteria analysis for locating sustainable suburban centers: A case study from Ramallah Governorate, Palestine. Cities, 28(5), pp.381-393.

Wang, H., 2013. A GIS-based framework for supporting sustainable land use planning in urban renewal projects(Doctoral dissertation, The Hong Kong Polytechnic University).

Kara, C. and Akçit, N., 2016, August. Monitoring urban growth and detection of land use with GIS and remote sensing: a case study of the Kyrenia region. In Fourth International Conference on Remote Sensing and Geoinformation of the Environment (RSCy2016) (Vol. 9688, p. 96881I). International Society for Optics and Photonics.
North
Cyprus
Natura
Protection
Site(2012)http://dogakoruma.eu( retrieved February 2018)

Dinç, A.O., 2008. Development of Soil Information System for the Turkish Republic of Northern Cyprus. 
Saaty, T. (1980). The Analytic Hierarchy Process. New York, U.S.A.: McGraw-Hill International.

Saaty, T. (1994). Fundamentals of Decision Making and Priority Theory with the AHP. Pittsburgh, PA, U.S.A: RWS Publications.

Eastman, J. (2001). Guide to GIS and Image Processing, Vol. 2. Massachusetts, USA: Clark University.

State planning organization (2011)" https://devplan.org “ . 